\title{
Extreme flood events at higher temperatures exacerbate the loss of soil functionality and trace gas emissions in grassland
}

Rafael Sanchez-Rodriguez, Antonio; Nie, Chengrong; Hill, Paul W.; Chadwick, David R.; Jones, Davey L.

\section{Soil Biology and Biochemistry}

DOI:

10.1016/j.soilbio.2018.12.021

Published: 01/03/2019

Peer reviewed version

Cyswllt i'r cyhoeddiad / Link to publication

Dyfyniad o'r fersiwn a gyhoeddwyd / Citation for published version (APA):

Rafael Sanchez-Rodriguez, A., Nie, C., Hill, P. W., Chadwick, D. R., \& Jones, D. L. (2019).

Extreme flood events at higher temperatures exacerbate the loss of soil functionality and trace gas emissions in grassland. Soil Biology and Biochemistry, 130, 227-236.

https://doi.org/10.1016/j.soilbio.2018.12.021

\footnotetext{
Hawliau Cyffredinol / General rights

Copyright and moral rights for the publications made accessible in the public portal are retained by the authors and/or other copyright owners and it is a condition of accessing publications that users recognise and abide by the legal requirements associated with these rights.

- Users may download and print one copy of any publication from the public portal for the purpose of private study or research.

- You may not further distribute the material or use it for any profit-making activity or commercial gain

- You may freely distribute the URL identifying the publication in the public portal ?
}

Take down policy

If you believe that this document breaches copyright please contact us providing details, and we will remove access to the work immediately and investigate your claim. 


\section{Accepted Manuscript}

Extreme flood events at higher temperatures exacerbate the loss of soil functionality and trace gas emissions in grassland

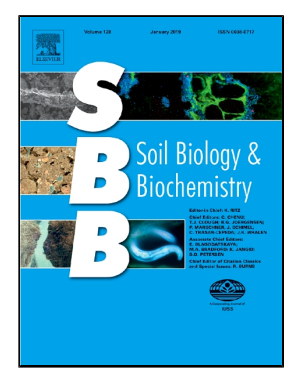

Antonio Rafael Sánchez-Rodríguez, Chengrong Nie, Paul W. Hill, David R.

Chadwick, Davey L. Jones

PII:

S0038-0717(18)30439-5

DOI:

10.1016/j.soilbio.2018.12.021

Reference:

SBB 7373

To appear in:

Soil Biology and Biochemistry

Received Date:

20 August 2018

Accepted Date:

20 December 2018

Please cite this article as: Antonio Rafael Sánchez-Rodríguez, Chengrong Nie, Paul W. Hill, David R. Chadwick, Davey L. Jones, Extreme flood events at higher temperatures exacerbate the loss of soil functionality and trace gas emissions in grassland, Soil Biology and Biochemistry (2018), doi: 10.1016/j.soilbio.2018.12.021

This is a PDF file of an unedited manuscript that has been accepted for publication. As a service to our customers we are providing this early version of the manuscript. The manuscript will undergo copyediting, typesetting, and review of the resulting proof before it is published in its final form. Please note that during the production process errors may be discovered which could affect the content, and all legal disclaimers that apply to the journal pertain. 
1 Extreme flood events at higher temperatures exacerbate the loss of soil functionality and

2 trace gas emissions in grassland

3 Antonio Rafael Sánchez-Rodríguez ${ }^{\mathrm{a}, \mathrm{b}, *}$, Chengrong Nie ${ }^{\mathrm{a}, \mathrm{c}}$, Paul W. Hill ${ }^{\mathrm{a}}$, David R. Chadwick ${ }^{\mathrm{a}}$,

4 Davey L. Jones ${ }^{\mathrm{a}, \mathrm{d}}$

$5 \quad{ }^{a}$ Environment Centre Wales, Bangor University, Gwynedd LL57 2UW, UK

6 b Departamento de Agronomía, Universidad de Córdoba, ETSIAM, Córdoba, Andalucía 14071,

$7 \quad$ Spain

8 ' School of Food Science \& Technology, Foshan University, Foshan 528231, Guangdong

9 Province, China

$10 \mathrm{~d}$ UWA School of Agriculture and Environment, University of Western Australia, Crawley, WA

11 6009, Australia

$12 \quad *$ Corresponding author. Tel.: +34 957218915

13 E-mail address: antonio.sanchez@uco.es (A.R. Sánchez-Rodríguez). 


\section{Abstract}

The frequency and intensity of extreme weather events (e.g. flood, drought) are predicted to increase for the foreseeable future and it is expected that these will negatively impact upon agroecosystem functioning. Our understanding of how grassland ecosystems respond to extreme weather events occurring at different times of the year, however, is lacking. To better understand the seasonal response of grassland to flooding, we subjected an agricultural grassland to an 8week extreme flood event at three different temperatures $\left(5^{\circ} \mathrm{C}\right.$-winter, $15^{\circ} \mathrm{C}$-spring/autumn and $25^{\circ} \mathrm{C}$-summer) and then followed its subsequent recovery for 9 weeks after floodwater removal. We focused on key indicators of ecosystem functioning including primary production, nutrient cycling, greenhouse gas (GHG) emissions, ammonia $\left(\mathrm{NH}_{3}\right)$ volatilization, and soil microbial communities. The experiment used intact soil mesocosms $(1 \mathrm{~kg})$ with indigenous vegetation collected from a grassland with no previous history of flooding. Flooding reduced biomass production by $18 \%$ at $5{ }^{\circ} \mathrm{C}, 50 \%$ at $15{ }^{\circ} \mathrm{C}$ and $95 \%$ at $25^{\circ} \mathrm{C}$. Flooding also significantly disrupted elemental cycling (nitrogen, phosphorus and carbon) as evidenced by an increased release of $\mathrm{P}$, $\mathrm{Fe}$ and $\mathrm{NH}_{4}{ }^{+}$into the soil and overlying floodwater and large amounts of $\mathrm{CH}_{4}$ and $\mathrm{NH}_{3}$ released to the atmosphere (mainly during the flooding). These effects were more pronounced at higher temperatures (e.g. 45 to $700 \mathrm{~kg} \mathrm{CH}_{4}-\mathrm{C}$ ha ${ }^{-1}$ and 1 to $5 \mathrm{~kg} \mathrm{NH}_{3}-\mathrm{N} \mathrm{ha}^{-1}$ at 15 and $25{ }^{\circ} \mathrm{C}$, respectively). In addition, after floodwater removal this $\mathrm{NH}_{4}{ }^{+}$was rapidly nitrified leading to large losses of $\mathrm{N}_{2} \mathrm{O}$ (1.0 to $14.2 \mathrm{~kg} \mathrm{~N}_{2} \mathrm{O}-\mathrm{N}$ ha ${ }^{-1}$ at 5 to $25{ }^{\circ} \mathrm{C}$, respectively). Especially at higher temperatures, flooding resulted in a reduction in soil microbial biomass (more than $58 \%$ of the equivalent unflooded treatment at $25^{\circ} \mathrm{C}$ ) and changes in microbial community structure (assessed by PLFAs). Further, some of these changes persisted after flood removal including a loss of actinomycetes, arbuscular mycorrhizal fungi and fungi. Overall, we conclude that ecosystem responses to extreme weather events are critically dependent on temperature with those occurring at higher temperatures having a greater negative impact than those at the lowest temperature (5 ${ }^{\circ} \mathrm{C}$ ). The large potential release of $\mathrm{CH}_{4}$ and $\mathrm{N}_{2} \mathrm{O}$ also suggests that flood events should be considered as a potential source of GHGs when comparing top-down and bottom-up calculations 
of national inventories, and that further work is needed to better refine GHG emission estimates for these events.

Keywords: Climate change, Nitrous oxide, Methane, Iron oxyhydroxide; PLFA; Soil microorganisms

\section{Introduction}

Climate change is increasing the incidence of extreme weather events (Slater and Villarini, 2016) and current predictions indicate that their frequency and intensity will increase for the foreseeable future (IPCC, 2014). These events constitute a major threat to the delivery of soil-related agroecosystem services such as biomass production, biodiversity conservation, erosion control, pest and disease control, water quality and supply, and climate regulation, resulting in a loss of soil functioning (Bünemann et al., 2018).

Under future global warming scenarios, increases in temperature will result in more intense rainfall events (a warmer atmosphere can hold more water), an acceleration of snow and ice melt, and an increase in sea level, thereby increasing the risk of flooding (Trenberth, 2011). It is also predicted that areas with no previous history of flooding will become increasingly affected (Thorne, 2014). Extreme flood events can occur throughout the year and can cover large land areas with floodwater persisting from days to months, with floodwater depths reaching up to $2 \mathrm{~m}$ (Met Office, 2014; Morris and Brewin, 2014; Posthumus et al., 2009; Romanescu and Stoleriu, 2017). The overall damage to agroecosystems appears to be dependent upon the time of year when floods occur (Posthumus et al., 2009), plant species and their growth stage (Morris and Brewin, 2014), the type of flooding and the preceding agricultural management regime (SánchezRodríguez et al., 2017, 2018b). At higher temperatures, chemical and biological soil reactions are accelerated and it is normally assumed that these will aggravate the effects of extreme flood events on plant production (Posthumus et al., 2009) and potential nutrient losses (Sánchez-Rodríguez et al., 2018b), however, colder weather also causes devastating effects if the crop is completely submerged (Das et al., 2009). It is also important to note that the impact of flooding on soil-based ecosystem services may continue after the floodwater has receded (Niu et al., 2014; Osanai et al., 2017). 
response to extreme weather events. For example, drought is expected to reduce GHG emissions as microbial activity becomes water-limited, whilst in contrast, flooding may increase net GHG emissions, due to a microbial switch from aerobic to anaerobic metabolism (Hou et al., 2000). Although $\mathrm{N}_{2} \mathrm{O}$ produced under aerobic conditions may be reduced, and $\mathrm{CH}_{4}$ emissions may increase under flooding, the overall mineralization of soil organic carbon (SOC) is typically suppressed due to the lack of $\mathrm{O}_{2}$ required for oxidative-based enzymatic processes (Miller et al., 2001). Interestingly, however, there is also evidence showing an increase in mineralization in waterlogged or flooded soils (Alongi et al., 2012), particularly at elevated temperatures (Kirwan and Blum, 2011) when $\mathrm{N}$ and $\mathrm{C}$, factors that limit decomposition rates of organic matter, are abundant.

In relation to plant biomass production and water quality, the release of nutrients and consequent loss of soil fertility may also be aggravated under prolonged inundation, altering the cycling of key nutrients (e.g. N, P, S; Bünemann et al., 2018). For example, under flooding and progressive anoxia, nitrification becomes inhibited leading to the net accumulation of $\mathrm{NH}_{4}{ }^{+}$which may subsequently lead to phytotoxicity and/or enhanced $\mathrm{NH}_{3}$ volatilization, while denitrification can lead to the loss of residual soil $\mathrm{NO}_{3}^{-}$as $\mathrm{N}_{2} \mathrm{O} / \mathrm{N}_{2}$, particularly when labile $\mathrm{SOC}$ is present (Senbayram et al., 2012). Under waterlogging, a drop in redox potential can cause the reduction and solubilisation of $\mathrm{Fe}^{3+}$ inducing the release of $\mathrm{P}$ held on the surfaces of Fe-oxyhydroxides. Ultimately, this can cause a redistribution of nutrients adsorbed on Fe oxides within the soil profile.

The deleterious effect of flooding on plant growth and soil functions appears to be critically dependent on the duration and timing of the event (Glaz and Lingle, 2012; Shao et al., 2013). Typically, little adverse effect is seen if the floodwater dissipates within 2 weeks, however, longer inundation periods may trigger major changes in soil functioning and ecosystem service delivery (Niu et al., 2014). Finally, the size and composition of the soil microbial community, a key driver for soil functioning and soil-based ecosystem services, is strongly affected by water content and temperature (Castro et al., 2010) and, traditionally, alterations in its structure have 
97

been described during flooding, such as a reduction in Gram- bacteria and an increase in Gram+ bacteria (Bossio and Scow, 1998).

Given the increased frequency of extreme flood events, it is important that we gain a better mechanistic understanding of how this affects soils both during and after flooding. The results obtained in this laboratory experiment under controlled conditions, which allow us to assess different scenarios easily, indicate the main alterations that could happen under field conditions. Field experiments dealing with extreme flooding events will benefit from the results obtained here. This will support the design of successful flood-amelioration strategies to offset the negative effects of flooding and will also inform future soil management regimes. As temperature is a key regulator of biochemical reaction rates in soil, we hypothesize that season will be one of the most important factors which determines the outcome of flooding on soil functioning, air quality and soil microbial communities. To evaluate this, we simulated an extreme flood event at $5{ }^{\circ} \mathrm{C}$ (winter flood), $15{ }^{\circ} \mathrm{C}$ (spring/autumn flood) and $25^{\circ} \mathrm{C}$ (summer flood) in a grassland soil with no previous history of flooding. We investigated nutrient dynamics and potential losses, GHGs emissions, $\mathrm{NH}_{3}$ volatilization, changes in soil microbial communities and biomass production during an extreme flooding event ( 8 weeks) and after the flood water was removed, during the recovery of these soils ( 9 weeks of recovery). Unflooded grassland soil at the same temperatures was used as baseline to compare with the flooded ones.

We selected a grassland soil because of its importance not only in the UK but also worldwide, and the services and soil functions that it provides, including its ability to improve soil $\mathrm{C}$ sequestration after a conversion from previously degraded soils (Hirsch et al., 2016). We hypothesized that the magnitude of the response will be more evident (a greater loss of soil functioning, a bigger deterioration of air quality, major alterations in the soil microbial communities and higher reductions in biomass production) and that different mechanisms and reactions will be involved at higher temperatures.

\section{Materials and methods}

\subsection{Soil sampling and soil characterization}


indigenous vegetation were collected from the top soil (Ah horizon) of a sheep-grazed grassland, $4^{\circ} 00^{\prime} 57^{\prime \prime} \mathrm{W}$ ) in spring 2016. The soil is classified as a Eutric Cambisol (IUSS Working Group WRB, 2015) with a sandy clay loam texture that receives each year $100 \mathrm{~kg} \mathrm{~N} \mathrm{ha}^{-1}, 20 \mathrm{~kg} \mathrm{P} \mathrm{ha}^{-1}$ and $20 \mathrm{~kg} \mathrm{~K} \mathrm{ha}^{-1}$. The site has a mean annual soil $\left(0-10 \mathrm{~cm}\right.$ ) temperature of $10{ }^{\circ} \mathrm{C}$ (daily mean ranges from -2.5 to $23{ }^{\circ} \mathrm{C}$ ) and annual rainfall of $1060 \mathrm{~mm}$.

A representative soil sample of one $\mathrm{kg}$ was collected from the same area, air-dried for one week at $25^{\circ} \mathrm{C}$ and sieved $(2 \mathrm{~mm})$ to characterize the main physical-chemical properties. The $\mathrm{pH}$ (6.0) and the electrical conductivity $\left(<0.1 \mathrm{dS} \mathrm{m}^{-1}\right)$ were determined in a 1:2.5 $(w / v)$ soil:distilled water suspension. Fifty $\mathrm{ml}$ of $0.5 \mathrm{M} \mathrm{BaCl}_{2}$ were used to extract the exchangeable bases from $5 \mathrm{~g}$ of soil, after shaking for $1 \mathrm{~h}$ at $20^{\circ} \mathrm{C}$, and the cations $\left(1600 \mathrm{mg} \mathrm{Ca} \mathrm{kg}{ }^{-1}, 120 \mathrm{mg} \mathrm{K} \mathrm{kg}^{-1}, 90 \mathrm{mg}\right.$ $\mathrm{Mg} \mathrm{kg}^{-1}, 30 \mathrm{mg} \mathrm{Na} \mathrm{kg}{ }^{-1}, 22 \mathrm{mg} \mathrm{Al} \mathrm{kg}{ }^{-1}$ ) analysed with a Series 720 ICP-OES (Agilent Technologies Inc., Santa Clara, CA). Total organic carbon $\left(\mathrm{C}, 21.0 \mathrm{~g} \mathrm{~kg}^{-1}\right)$ and nitrogen $(\mathrm{N}, 1.6$ $\mathrm{g} \mathrm{kg}^{-1}$ ) in soil were determined using a CHN-2000 analyser (Leco Corp., St Joseph, MI). $\left.\mathrm{kg}^{-1}\right)$ and $\mathrm{NO}_{3}^{-}\left(14.0 \mathrm{~g} \mathrm{~kg}^{-1}\right)$ in the extract were determined colorimetrically according to Mulvaney (1996) and Miranda et al. (2001), respectively, using a PowerWave-XS microplate reader (BioTek Instruments Inc., Winooski, VT). Finally, P availability index $\left(10.0 \mathrm{~g} \mathrm{~kg}^{-1}\right)$ was measured according to the molybdate blue method of Murphy and Riley (1962), after extracting P from the soil $\left(1 \mathrm{~h}, 200 \mathrm{rev} \mathrm{min}^{-1}\right)$ using a 1:5 $(w / v)$ soil:0.5 M acetic acid solution.

\subsection{Experimental design, treatments and phases of the experiment}

The twenty-four intact soil blocks were placed at the bottom of transparent containers made of polypropylene $(11 \times 8 \mathrm{~cm}$ base and $27 \mathrm{~cm}$ high; Lock \& Lock Ltd., Seoul, Republic of Korea) and distributed equally among three identical Fitotron ${ }^{\circledR}$ plant growth chambers (Weiss Technik UK Ltd, Ebbw Vale, UK) with a photoperiod of $16 \mathrm{~h} \mathrm{~d}^{-1}$, light intensity of $350 \mu \mathrm{mol} \mathrm{m}{ }^{-2}$ 
$153 \mathrm{~s}^{-1}$, and relative humidity of $70 \%$, each one with a different temperature, $5{ }^{\circ} \mathrm{C}, 15{ }^{\circ} \mathrm{C}$ or $25{ }^{\circ} \mathrm{C}$,

154 for the whole length of the experiment. A Rhizon ${ }^{\circledR}$ sampler $(0.15 \mu \mathrm{m}$ pore size; Rhizosphere

155 Research Products, Wageningen, The Netherlands) was inserted into the middle of each soil block

156 at an angle of $45^{\circ}$ and a depth of $5 \mathrm{~cm}$ at the beginning of the experiment to recover soil solution

157 throughout the experiment (i.e. to minimize damage to soil structure and indigenous vegetation).

158 This experiment had three distinct phases:

159 (1) Pre-flood phase: During the first $20 \mathrm{~d}$ of the experiment, the plant-soil mesocosms were kept

160 field-moist (ca. $75 \%$ of field capacity) weighing them twice per week and watering individually

161 with oligotrophic water collected from the Aber River (53 $3^{\circ} 14^{\prime} 09^{\prime \prime} \mathrm{N}, 4^{\circ} 01^{\prime} 01^{\prime}$ ' W), located near

162 to the field where the plant and soil samples were taken. The concentration of nutrients in the river water was low $\left(3.1 \mathrm{mg} \mathrm{C} \mathrm{L}^{-1}, 0.16 \mathrm{mg} \mathrm{NO}_{3}-\mathrm{N} \mathrm{L}^{-1}, 0.01 \mathrm{mg} \mathrm{NH}_{4}-\mathrm{N} \mathrm{L}^{-1}, 0.04 \mathrm{mg} \mathrm{P} \mathrm{L}{ }^{-1}, \mathrm{pH}\right.$ $6.5)$.

(2) Flood-phase: Four mesocosms at each temperature $\left(5^{\circ} \mathrm{C}, 15^{\circ} \mathrm{C}\right.$ and $\left.25^{\circ} \mathrm{C}\right)$ were flooded $(\mathrm{F})$ with $0.9 \mathrm{~L}$ of river water while the other four were watered with river water to keep field-moist (C). The three temperatures were designed to simulate winter, spring/autumn and summer flooding temperatures, although the rest of variables were the same (moisture of the growth chambers, photoperiod, light intensity), to assess the effect of the temperature (main objective). The floodwater depth was maintained $10 \mathrm{~cm}$ above the soil surface for eight weeks reflecting unprecedented flooding events observed in the general region in 2016. The treatments were called control $5{ }^{\circ} \mathrm{C}$, control $15{ }^{\circ} \mathrm{C}$, control $25^{\circ} \mathrm{C}$, flood $5{ }^{\circ} \mathrm{C}$, flood $15{ }^{\circ} \mathrm{C}$ and flood $25{ }^{\circ} \mathrm{C}$. Therefore, six treatments from the combination of the factor temperature $\left(5{ }^{\circ} \mathrm{C}, 15^{\circ} \mathrm{C}\right.$ and $\left.25{ }^{\circ} \mathrm{C}\right)$ and flood/non-flood and four mesocosms per treatment were used in this experiment.

(3) Soil recovery phase: The last phase started by carefully removing the floodwater from the containers that were flooded in the previous stage. Non-flooded, field-moist conditions were subsequently maintained for nine weeks in all 24 mesocosms. 

PowerBase-XS microplate reader (BioTek Instruments Inc., Winooski, VT) was used for the colorimetric determination of P (Murphy and Riley, 1962), Fe (Loeppert and Inskeep, 1996), $\mathrm{NH}_{4}{ }^{+}$(Mulvaney, 1996) and $\mathrm{NO}_{3}^{-}$(Miranda et al., 2001). The potential losses of these nutrients were calculated from the maximum concentrations measured in the soil solution and floodwater during the flood phase $\left(C_{\text {release }}\right.$, Eqn. 1):

$$
C_{\text {release }}\left(\mathrm{mg} \text { mesocosm }{ }^{-1}\right)=\left[C_{\text {sol }} \times V_{\text {soil }} \times \Theta\right]+\left[C_{\text {flood }} \times V_{\text {flood }}\right]
$$

where $C_{\text {sol }}$ and $C_{\text {flood }}$ are the concentration of a nutrient in the soil solution and floodwater respectively, $V_{\text {soil }}$ and $V_{\text {flood }}$ are the volume of soil (0.7 1) and floodwater (0.9 1) respectively and $\Theta$ is the volumetric water content $\left(0.5 \mathrm{~m}^{3} \mathrm{~m}^{-3}\right)$. with rubber septum was used to hermetically seal the containers. At time $0 \mathrm{~h}$ and $1 \mathrm{~h}$, the headspace gas was then sampled using a syringe and extracted gas samples placed in preevacuated gas-tight glass vials $(22 \mathrm{ml})$. The concentrations of GHG in the vials was measured using a Clarus 500 gas chromatograph equipped with a HS-40 Turbomatrix autoanalyzer (PerkinElmer Inc., Waltham, MA); $\mathrm{CH}_{4}$ and $\mathrm{CO}_{2}$ were detected with a flame ionization detector (FIC) connected to a methanizer and $\mathrm{N}_{2} \mathrm{O}$ with a ${ }^{63} \mathrm{Ni}$ electron-capture detector. Greenhouse gas fluxes were calculated with the difference of each gas concentration at time 0 and $1 \mathrm{~h}$ after correction for temperature and the ratio between chamber volume and soil surface area (Mackenzie et al., 1998). cumulative fluxes were estimated by multiplying the mean of two successive daily fluxes by the number of hours between these gas samplings and summing that value to the previous cumulative 
208

209

210

211

212

213

214

215

216

217

218

219

220

221

222

223

224

225

226

227

228

229

230

231

232

233

234

235

total. The global warming potential (GWP) of the GHGs was estimated in $\mathrm{CO}_{2}$ equivalents by multiplying the total cumulative fluxes by 34 for $\mathrm{CH}_{4}, 1$ for $\mathrm{CO}_{2}$ and 298 for $\mathrm{N}_{2} \mathrm{O}$ before summing them (IPCC, 2013).

Ammonia volatilization was estimated by trapping evolved $\mathrm{NH}_{3}$ using headspace acid traps. Briefly, $25 \mathrm{~mm}$ diameter glass microfiber filters saturated with $0.15 \mathrm{M} \mathrm{H}_{3} \mathrm{PO}_{4}$ (one per mesocosm and sampling; Whatman GmbH, Dassel, Germany) were suspended on the underside of the container lids (while GHG sampling). After one hour in contact with the air inside the hermetically closed container, the filters were removed and the filter papers extracted with $1 \mathrm{ml}$ of distilled water $\left(1 \mathrm{~h}, 200 \mathrm{rev} \mathrm{min}^{-1}\right)$ before colorimetric determination of $\mathrm{NH}_{4}{ }^{+}$in the extract according to the salicylic acid-hypochlorite procedure of Mulvaney (1996). Weekly samplings were done from the beginning of the flooding to the fourth week of soil recovery.

\subsection{Soil biological indicators}

Soil (25 g) was removed from each mesocosm at the beginning and end of the soil recovery phase, sieved to $2 \mathrm{~mm}$ and stored at $-80^{\circ} \mathrm{C}$. Subsequently, the samples were freezedried and phospholipid fatty acid (PLFA) analysis undertaken according to Bartelt-Ryser et al. (2005) with taxonomic groups ascribed to individual PLFAs using the Sherlock ${ }^{\circledR}$ PLFA Method and Tools Package (PLFAD1; Microbial ID Inc., Newark, DE). One hundred and two fatty acids were identified in the soil samples, however, we only present results from the twenty-nine whose concentration was higher than $0.5 \%$ of the total PLFAs (and the one used as a biomarker for protozoa which only constituted $0.4 \%$ of the total PLFAs), classified per taxonomic group (Bartelt-Ryser et al., 2005; Bedard and Knowles, 1989; Bossio and Scow, 1998; Bowman et al., 1991, 1993; Kieft et al., 1994; Niklaus et al., 2003; Olsson et al., 1999; Paul and Clark, 1996; Ratledge and Wilkinson, 1988; Zelles, 1999):

14:0 iso, 15:0 iso, 15:0 anteiso, 15:1 iso $\omega$ cc, 16:0 iso, 17:0 iso, 17:0 anteiso and 17:1 iso $\omega 9 \mathrm{c}$ were used for Gram+ bacteria; $16: 1 \omega 5 \mathrm{c}, 16: 1 \omega 7 \mathrm{c}, 16: 1 \omega 9 \mathrm{c}, 17: 1 \omega 8 \mathrm{c}, 17: 0$ cyclo $\omega 7 \mathrm{c}, 18: 1$ $\omega 5 \mathrm{c}, 18: 1 \omega 7 \mathrm{c}, 18: 1 \omega 9 \mathrm{c}$ and 19:0 cyclo $\omega 7 \mathrm{c}$ were used for Gram- bacteria; 16:0 10 methyl, 17:1 $\omega 7 \mathrm{c} 10$ methyl, 18:0 10 methyl and 18:1 $\omega 7 \mathrm{c} 10$ methyl for actinomycetes; 15:0 DMA as 
236

237

238

239

240

241

242

243

biomarker for anaerobic bacteria; $20: 4 \omega 6 \mathrm{c}$ for protozoa; $18: 2 \omega 6 \mathrm{c}$ for fungi; and 16:1 $\omega 5 \mathrm{c}$ as biomarker for putative arbuscular mycorrhizal fungi; 14:0, 15:0, 16:0, 17:0, 18:0 were found but were not assigned to a specific taxonomic group.

At the end of the soil recovery phase, the grass was cut, and dry weight recorded after oven drying $\left(80^{\circ} \mathrm{C}, 48 \mathrm{~h}\right)$ to establish how the different treatments altered plant productivity.

\subsection{Statistical analysis}

Analysis of variance (ANOVA) with six treatments (three temperatures, 5, 15 and $25{ }^{\circ} \mathrm{C}$, with and without flood) and four replications per treatment was used to determine differences in potential losses of nutrients, cumulative GHG fluxes, GWP, cumulative apparent $\mathrm{NH}_{3}$ and plant biomass at the end of the experiment, and microbial biomass and taxonomic groups (PLFAs) after the flood phase and after the soil recovery phase. When significant differences were found $(p<$ 0.05), Tukey's HSD post hoc was used to separate means of the six treatments. Potential losses of $\mathrm{Fe}$ and $\mathrm{NO}_{3}^{-}$, cumulative $\mathrm{CH}_{4}$ and $\mathrm{N}_{2} \mathrm{O}$ fluxes, and plant biomass were $\log 10$-transformed, and putative arbuscular mycorrhiza was squared-transformed, to meet the requirements for ANOVA. Principal component analysis (PCA) based on a data correlation matrix with principal components (PCs) was developed at the end of the flood phase and after soil recovery to evaluate alterations in soil microbial communities (PLFAs, taxonomic groups).

All the statistical analyses were performed in the statistical package SPSS software v22.0 (IBM Inc., Armonk, NY) except for the PCA, which was done in R' (R Core Team, 2003) with the Vegan package (Oksanen et al., 2018) to include additional variables (pH, $\mathrm{P}, \mathrm{Fe}, \mathrm{NH}_{4}{ }^{+}, \mathrm{NO}_{3}^{-}$, GHG fluxes and apparent $\mathrm{NH}_{3}$ ) as environmental factors based on their correlations with the different taxonomic groups. Significance was evaluated using the permutation test (Bonferroni's correction).

\section{Results}

3.1. pH, soil nutrient dynamics and potential losses 

of the experiment (Fig. 1a). The lowest values were measured for the containers at $5{ }^{\circ} \mathrm{C}$ while the highest pHs were measured in the soil solution of the unflooded mesocosms at $25{ }^{\circ} \mathrm{C}$ except in the last three samplings for the flooded containers at $25^{\circ} \mathrm{C}$. The $\mathrm{pH}$ in the floodwater increased with temperature (Fig. 1b).

The concentration of $\mathrm{P}$ in the soil solution was also variable throughout the experiment but a general trend in which the highest concentrations were measured for the mesocosms with the lowest temperatures (in 13 of 17 samplings) was observed (Fig. 1c). The trend was the opposite for the $\mathrm{P}$ released into the floodwater, with the lowest concentration of $\mathrm{P}$ found in the floodwater of the flooded mesocosms at $5{ }^{\circ} \mathrm{C}$ (Fig. 1d). Iron in the soil solution was much greater in the flooded treatments than in the control ones, peaking at around $15 \mathrm{mg} \mathrm{Fe} \mathrm{L}^{-1}$ one week after the flood started for the containers at $25{ }^{\circ} \mathrm{C}$ and the last week of the flooding phase for the containers at $15^{\circ} \mathrm{C}$, and around $6 \mathrm{mg} \mathrm{Fe} \mathrm{L}^{-1}$ in the last week of the flood phase for the containers at $5{ }^{\circ} \mathrm{C}$ (Fig. 1e). The concentration of $\mathrm{Fe}$ in the soil solution of the unflooded treatments was negligible in most occasions and below $3 \mathrm{mg} \mathrm{Fe} \mathrm{L}^{-1}$ in the rest. As for $\mathrm{P}$, the release of $\mathrm{Fe}$ into the floodwater was positively related to temperature, except in the last two weeks of the flood phase when the highest concentrations of Fe were found in the mesocosms at $15^{\circ} \mathrm{C}$ (Fig. 1f). The time course of $\mathrm{NH}_{4}{ }^{+}$in the soil solution and floodwater followed a similar pattern as described for $\mathrm{Fe}$, with negligible concentrations in the pre-flood phase but which rapidly increased and peaked as a function of the temperature $\left(25>15>5{ }^{\circ} \mathrm{C}\right.$; Figs. 2ab). A gradual reduction in soil solution $\mathrm{NH}_{4}{ }^{+}$concentration was seen when the floodwater was removed in all treatments. In contrast, the initial concentrations of $\mathrm{NO}_{3}{ }^{-}$in soil solution were between 6 and $30 \mathrm{mg} \mathrm{N} \mathrm{L}^{-1}$ but then, during the flood phase, they remained low except for the unflooded mesocosms at $5{ }^{\circ} \mathrm{C}$, in which these concentrations were higher than for the rest of the unflooded mesocosms (but always below $12 \mathrm{mg} \mathrm{N} \mathrm{L}^{-1}$; Fig. 2c). These concentrations were lower than $4 \mathrm{mg} \mathrm{N} \mathrm{L}^{-1}$ in the floodwater of the three treatments (Fig. 2d). However, $\mathrm{NO}_{3}{ }^{-}$in the soil solution of the flooded containers in the soil recovery phase reached values of nearly $60 \mathrm{mg} \mathrm{N} \mathrm{L}^{-1}$ at $25^{\circ} \mathrm{C}$ and $12 \mathrm{mg} \mathrm{N} \mathrm{L}^{-1}$ at $15^{\circ} \mathrm{C}$. 
291 flooding. In general, the combination of flooding $\times$ higher temperatures significantly $(p<0.001)$ increased the potential losses $\left(\mathrm{kg} \mathrm{ha}^{-1}\right)$ of P (between $5.0 \pm 0.2$ and 9.6 \pm 0.7$)$, Fe (between $3.9 \pm$

0.6 and 13.7 \pm 1.3 ) and $\mathrm{NH}_{4}{ }^{+}$(between $2.4 \pm 0.4$ and $17.3 \pm 1.0$ ) in comparison with the unflooded mesocosms (1.9 $\mathrm{kg} \mathrm{ha}^{-1}$ for $\mathrm{P}$ and lower than $0.5 \mathrm{~kg} \mathrm{ha}^{-1}$ for $\mathrm{Fe}$ and $\mathrm{NH}_{4}{ }^{+}$, Table 1).

\subsection{GHG fluxes and apparent $\mathrm{NH}_{3}$ volatilization}

Daily GHG fluxes and apparent $\mathrm{NH}_{3}$ volatilization are shown in Figure 3. Significant $\mathrm{CH}_{4}$ emissions were only detected during the flood phase and the day after the floodwater was removed for the 15 and $25{ }^{\circ} \mathrm{C}$ flooding treatments only (Fig. 3a). These daily emissions were greater and more prolonged at $25{ }^{\circ} \mathrm{C}$ than at $15{ }^{\circ} \mathrm{C}$, reaching up to 90 and $25 \mathrm{mg} \mathrm{C} \mathrm{m}^{-2} \mathrm{~h}^{-1}$, respectively. In the case of $\mathrm{CO}_{2}$, daily fluxes were higher in the flooded mesocosms than in the control ones, except for the first gas sampling period (Fig. 3b). Above-background $\mathrm{N}_{2} \mathrm{O}$ fluxes were only detected during the soil recovery phase for two treatments, peaking at $3.2 \mathrm{mg} \mathrm{N} \mathrm{m}^{-2} \mathrm{~h}^{-1}$ for the flooded containers at $25{ }^{\circ} \mathrm{C}$ and around $1 \mathrm{mg} \mathrm{N} \mathrm{m}^{-2} \mathrm{~h}^{-1}$ for those held at $15^{\circ} \mathrm{C}$, one week and four weeks after flood removal, respectively (Fig. 3c). Finally, $\mathrm{NH}_{3}$ emissions were concentrated in the flood phase and only occurred in the flooded mesocosms at the two highest temperatures, reaching up to $0.75 \mathrm{mg} \mathrm{N} \mathrm{m}^{-2} \mathrm{~h}^{-1}$ at $25^{\circ} \mathrm{C}$ and $0.15 \mathrm{mg} \mathrm{N} \mathrm{m}^{-2} \mathrm{~h}^{-1}$ at $15{ }^{\circ} \mathrm{C}$ (Fig. $3 \mathrm{~d}$ ). $\mathrm{CH}_{4}$ and $\mathrm{N}_{2} \mathrm{O}$ fluxes (Table 2$)$. The highest cumulative fluxes $(p<0.001)$ were produced in the flooded containers at $25{ }^{\circ} \mathrm{C}$, followed by the ones at $15{ }^{\circ} \mathrm{C}$, and then the rest of combinations. Negative cumulative $\mathrm{CO}_{2}$ fluxes were calculated for the unflooded mesocosms at 15 and $25{ }^{\circ} \mathrm{C}$. GWP was significantly higher $(p<0.001)$ for the flooded mesocosms at $25{ }^{\circ} \mathrm{C}$ in comparison with the rest of the treatments (Table 2), with $\mathrm{CH}_{4}$ accounting for $82 \%$ of the GWP for this treatment. Finally, cumulative $\mathrm{N}$ losses due to apparent $\mathrm{NH}_{3}$ volatilization were significantly higher $(p<0.001)$ for the flooded mesocosms at $25^{\circ} \mathrm{C}$, followed by flooded mesocosms at $15^{\circ} \mathrm{C}$, and lastly, by the rest of mesocosms. 


\subsection{Soil microbial communities}

Flooding at different temperatures significantly altered the size and structure of the soil microbial communities, some of which persisted through to the end of the soil recovery phase. Soil microbial biomass was significantly reduced $(p<0.001)$ for the combination flood $\times 25{ }^{\circ} \mathrm{C}$ to $58.8 \%$ of the equivalent unflooded treatment at the end of the flooding, and to $66.7 \%$ after soil recovery (Table 3). Gram+ bacteria $(\%)$ were increased $(p<0.001)$ due to the effect of flooding and higher temperature after the floodwater phase, while a similar effect occurred for Grambacteria after the soil recovery in the flooded mesocosms ( $p<0.001$ for both). Actinomycetes were negatively affected $(p=0.002$ and $p<0.001)$ by temperature for the flooded containers, especially in the second sampling. Flooding produced the lowest (at $5^{\circ} \mathrm{C}$ ) and the highest (at 25 $\left.{ }^{\circ} \mathrm{C}\right)$ percentage of protozoa after soil recovery $(p=0.032)$. The proportion of putative arbuscular mycorrhiza fungi and fungi (\%) both decreased with increasing temperature but mainly because of the combination flooding $\times$ higher temperatures. Fungi after soil recovery (Table 3 ) was an exception to this where the $25^{\circ} \mathrm{C}$ flooded mesocosms were found to have the highest percentage of fungi.

The PCA for the different taxonomic groups (PLFAs) and their relationships with the environmental variables is shown in Fig. 4a. The separation of treatments after the flood phase and soil recovery can be seen in Fig. $4 \mathrm{~b}$ and Fig. 4c, respectively. The first PC, accounting for $55 \%$ of the total variance, was related with opposing shifts in Gram- bacteria and actinomycetes.

The second PC explained $30 \%$ of the total variance and was mainly related to the abundance of Gram+ bacteria. The differences between soil microbial communities were more evident at higher temperatures and in the first sampling (Figs. 4bc), with a similar microbial structure for the lowest temperature in flooded and unflooded mesocosms after soil recovery (Fig. 4c).

On one hand, the flooded mesocosms, in the order $25{ }^{\circ} \mathrm{C}>15{ }^{\circ} \mathrm{C}>5{ }^{\circ} \mathrm{C}$, were more related to higher $\mathrm{pH}$, solution nutrient concentration (except for $\mathrm{NO}_{3}{ }^{-}$), higher $\mathrm{GHG}$ fluxes $\left(\mathrm{CH}_{4}\right.$ after the flood phase and $\mathrm{N}_{2} \mathrm{O}$ after soil recovery), Gram+ bacteria after the flood phase and Gram- bacteria after soil recovery. On the other hand, the unflooded containers, in the order 25 ${ }^{\circ} \mathrm{C}>15{ }^{\circ} \mathrm{C}>5{ }^{\circ} \mathrm{C}$, were more related to higher $\mathrm{NO}_{3}-$ in soil solution, actinomycetes and putative 

arbuscular mycorrhiza contents, with this effect clearer after the flood phase (Fig. 4b) than after the soil recovery (Fig. 4c). Some significant correlations between the PCs and the environmental variables were found: $\mathrm{pH}(r=0.59, p=0.009), \mathrm{Fe}(r=0.75, p=0.009), \mathrm{NH}_{4}^{+}(r=0.59, p=$ $0.018), \mathrm{CH}_{4}(r=0.71, p=0.009), \mathrm{CO}_{2}(r=0.65, p=0.009)$ and apparent $\mathrm{NH}_{3}(r=0.75, p=$ $0.009)$.

\subsection{Plant biomass}

The plants growing in the flooded mesocosms at 15 and $25{ }^{\circ} \mathrm{C}$ started showing chlorosis two weeks after the floodwater was added and even necrosis in some of the leaves. Damage was greatest at the highest temperature, but no visual differences were observed between the plants growing in the control and flooded containers at $5{ }^{\circ} \mathrm{C}$. The vegetation in the flooded containers at $25^{\circ} \mathrm{C}$ completely died after 3-4 weeks of flooding. Overall, flooding limited plant dry weight $(\mathrm{kg}$ $\left.\mathrm{m}^{-2}\right)$ at $5{ }^{\circ} \mathrm{C}(0.82 \pm 0.09$ vs $0.68 \pm 0.10), 15^{\circ} \mathrm{C}(1.49 \pm 0.03$ vs $0.75 \pm 0.44)$ and $25^{\circ} \mathrm{C}(2.68 \pm$ 0.15 vs $0.12 \pm 0.09$ ), although the difference only proved significant at $25^{\circ} \mathrm{C}$ (Fig. 5).

\section{Discussion}

\subsection{Biomass production, element cycling and water quality}

Our study showed a clear interactive effect of flooding and temperature on soil functions or processes within intact grassland mesocosms. It is clear that temperature is a dominant factor regulating biomass production and soil functions under an extreme flood event: a biomass reduction of $95 \%$ relative to the controls was observed at $25{ }^{\circ} \mathrm{C}$. This mirrors the devastating effects that spring and summer floods have been shown to have on agricultural production (loss of crop quality and yield), even when the length of the event is short (3-4 weeks) (Klaus et al., 2016; Posthumus et al., 2009).

Flooding induced rapid changes in many soil chemical quality indicators, with the effects seen faster at elevated temperatures $\left(25>15>5{ }^{\circ} \mathrm{C}\right)$. Although $\mathrm{P}$ and $\mathrm{NO}_{3}{ }^{-}$in soil solution were in general lower at the end of the experiment than at the beginning, the majority of these indicators returned to their pre-flood values after a few weeks of soil recovery demonstrating the resilience 
374

375

of this grassland soil which has no previous history of inundation (Sánchez-Rodríguez et al., 2017). However, the extreme events induced a release of nutrients ( $\mathrm{P}, \mathrm{Fe}$ and $\mathrm{N}$ in the form of $\mathrm{NH}_{4}^{+}$) from the system and a significant increase of their potential losses, especially at high temperatures. Nutrient losses could pollute new areas where the floodwater is discharged, contribute to the eutrophication of adjacent water bodies or even produce toxicity due to soil accumulation of phytotoxic elements (e.g. Fe or Mn; Millaleo et al., 2010). Therefore, an immediate reduction in soil fertility may be expected after an extreme flood event. Although it will depend on the soil, nutrient content and bioavailability it could affect grassland sustainability and resilience under future events. In addition, in a scenario in which the frequency of extreme flood events and mean global temperature are increasing, soil functions and processes such as habitat provision, element cycling and water cycling (water quality) could be damaged to a greater extent if no alleviation measures are implemented.

Soil solution $\mathrm{pH}$ was highly variable and provided a poor indicator of alterations caused by flooding. A large drop in redox potential and the release of Fe into solution was predicted to induce the release of $\mathrm{P}$ held on Fe oxide surfaces. Little evidence for this was seen, however, suggesting that any P released was either immobilized in the microbial biomass, re-sorbed to other mineral surfaces [e.g. $\mathrm{Al}(\mathrm{OH})_{3}$ ], or was taken up by living plants (at 5 and $15^{\circ} \mathrm{C}$ ). The loss of $\mathrm{P}$ to the floodwater we ascribe to the decomposition and release of $\mathrm{P}$ from the above-ground vegetation (Sánchez-Rodríguez et al., 2019).

The $\mathrm{N}$ cycle suffered significant alterations depending on the temperature of the flood event. As expected, nitrification was limited during the flood phase (Nielsen et al., 1996). Evidence for nitrification was only found for the control treatment at the lowest temperature (really low $\mathrm{NO}_{3}{ }^{-}$concentrations in the soil solution and lack of $\mathrm{N}_{2} \mathrm{O}$ emissions for the rest of the temperatures). We hypothesize that plant uptake of inorganic $\mathrm{N}$ most likely explains their low concentration in the unflooded mesocosms and to a lesser extent for the flooded mesocosms as plants growing in these conditions close their stomata and reduce the uptake of water soluble nutrients as a response (Milroy and Bange, 2013). There was an accumulation of $\mathrm{NH}_{4}^{+}$in the flooded mesocosms (soil solution and floodwater) that we hypothesise could have had two 
402

403

404

405

406

407

408

409

410

411

412

413

414

415

416

417

418

419

420

421

422

423

424

425

426

427

428

429

different origins and contributions depending on the temperature: (1) mineralization of organic matter which increases with temperature (Kirwan and Blum, 2011); and (2) death of plants at higher flood temperatures, reducing the possibility of plant $\mathrm{NH}_{4}{ }^{+}$uptake.

This $\mathrm{NH}_{4}{ }^{+}$accumulation occurred rapidly in the flooded mesocosms at $25^{\circ} \mathrm{C}$ (peaking 7 $\mathrm{d}$ after flooding for soil solution, and $14 \mathrm{~d}$ for the floodwater), and a bit slower for the mesocosms at $15{ }^{\circ} \mathrm{C}$ (peaking after three-four weeks of flooding), in comparison with the containers at $5{ }^{\circ} \mathrm{C}$. A considerable decrease in these $\mathrm{NH}_{4}{ }^{+}$concentrations was observed at the two highest temperatures during the flood phase, probably due to $\mathrm{NH}_{3}$ volatilization as seen by Chen et al. (2015) for prolonged flooded rice crops. After that, a rapid reduction in $\mathrm{NH}_{4}{ }^{+}$concentration in the soil solution of the flooded containers was seen during soil recovery, linked to an increase in $\mathrm{NO}_{3}{ }^{-}$ and $\mathrm{N}_{2} \mathrm{O}$ emissions, higher at higher temperatures, indicating that the nitrifier population was unaffected by flooding. This is in line with $\mathrm{Xu}$ et al. (2016) who reported an increase in gene abundance and activity of the nitrifiers with temperature.

\subsection{Air quality and global warming potential}

The release of $\mathrm{CH}_{4}$ was seen only during the flood phase and the day the floodwater was removed. We ascribe the latter to the degassing of $\mathrm{CH}_{4}$ previously trapped in soil pores rather than de novo production. Methane production under flooding was clearly enhanced by the temperature and were analogous to those measured by Zhou et al. (2018) for subtropical permanently flooded rice paddy fields in China (up to $900 \mathrm{~kg} \mathrm{CH}_{4}-\mathrm{C} \mathrm{ha}^{-1} \mathrm{yr}^{-1}$ ). We speculate that the rapid death of roots, particularly at high temperatures, led to the release of labile $\mathrm{C}$ into the soil supporting microbial activity and fuelling a rapid lowering of the redox potential below -100 $\mathrm{mV}$ and production of $\mathrm{CH}_{4}$ (Hou et al., 2000). Alternatively, this process could have been driven by the release of lactic acid and ethanol into the soil from live roots under hypoxia (i.e. respiratory C dumping; Jones et al., 2009). The loss of alternative electron acceptors from soil solution (e.g. $\mathrm{NO}_{3}{ }^{-}$) alongside the rapid accumulation and stabilization of the end-products (e.g. $\mathrm{Fe}^{2+}$ ) also suggests a very rapid drop in redox potential at higher temperatures. The rapid cessation of $\mathrm{CH}_{4}$ production after removal of floodwater and the evidence for the emergence of more superior 
430

431

432

433

434

435

436

437

alternative electron acceptors $\left(\mathrm{NO}_{3}{ }^{-}, \mathrm{Fe}^{3+}\right)$, however, suggests that methanogenic activity was rapidly inhibited or that any $\mathrm{CH}_{4}$ produced was consumed by methanotrophs.

The daily and cumulative $\mathrm{CO}_{2}$ fluxes were higher in the mesocosms where the vegetation had a lower photosynthetic activity, under flooding at $25^{\circ} \mathrm{C}$ (no plants survived), and the lowest $\mathrm{CO}_{2}$ fluxes were measured for the unflooded mesocosms at 15 and $25^{\circ} \mathrm{C}$, which had the highest fixation of $\mathrm{C}$ and biomass production. This is the opposite to that observed in similar experiments without vegetation (Sánchez-Rodríguez et al., 2018b), but agrees with Lewis et al. (2014) for fluxes measured in vegetated coastal wetlands. Overall, the total amount of gaseous $\mathrm{C}$ loss $\left(\mathrm{CO}_{2}\right.$ $+\mathrm{CH}_{4}$ ) from the most impacted treatment (flood, $25{ }^{\circ} \mathrm{C}$ ) was $1.2 \mathrm{~g} \mathrm{C} \mathrm{kg}^{-1}$ over the $49 \mathrm{~d}$ experimental period. Probably, this high C flux is in part due to the large amount of decaying plant material which is senescing and being broken down. It would be interesting to compare these values with the results obtained in future field experiments under similar temperatures (winter/spring-autumn/summer flood events) to quantify how extreme flood events could affect long-term C storage.

In our experiment, $\mathrm{N}_{2} \mathrm{O}$ was only produced in significant quantities in the recovery phase. At the start of the experiment the soil solution $\mathrm{NO}_{3}{ }^{-}$concentrations were low and it is highly likely that most of this was fully denitrified to $\mathrm{N}_{2}$ shortly after flooding (Reddy and Patrick Jr., 1975). It is well established, however, that $\mathrm{N}_{2} \mathrm{O}$ production is optimal at water filled pore space values of between $60-70 \%$ which would have occurred after flood water removal (Bateman and Baggs, 2005). This soil is known to have an intrinsically high net nitrification rate (ca. $0.42 \mathrm{mg} \mathrm{N} \mathrm{kg}{ }^{-1}$ $\mathrm{d}^{-1}$; Jones et al., 2004), and therefore $\mathrm{N}_{2} \mathrm{O}$ may have been produced via both nitrification and/or denitrification as the $\mathrm{NH}_{4}^{+}$accumulated during flooding (ca. $5 \mathrm{mg} \mathrm{N} \mathrm{kg}$ ) was subsequently converted to $\mathrm{NO}_{3}{ }^{-}$. At $25^{\circ} \mathrm{C}$, the $\mathrm{N}_{2} \mathrm{O}$ emission window lasted ca. $22 \mathrm{~d}$ with a mean $\mathrm{N}_{2} \mathrm{O}$ flux of $0.51 \mathrm{mg} \mathrm{N}{ }_{2} \mathrm{O}-\mathrm{N} \mathrm{kg}^{-1} \mathrm{~d}^{-1}$ (i.e. $11.2 \mathrm{mg} \mathrm{N}_{2} \mathrm{O}-\mathrm{N} \mathrm{kg}^{-1}$ ). This indicates that $\mathrm{N}_{2} \mathrm{O}$ was also produced from de novo mineralization of soil organic $\mathrm{N}(\mathrm{SON})$ after floodwater removal, presumably in response to an accelerated turnover of the soil microbial community and the removal of $\mathrm{O}_{2}$ limitation on SON breakdown (pool size $1600 \mathrm{mg} \mathrm{N} \mathrm{kg}$ ) after flood water removal. Our measured fluxes (equivalent to 6 and $14 \mathrm{~kg} \mathrm{~N}_{2} \mathrm{O}-\mathrm{N} \mathrm{ha}{ }^{-1}$ at 15 and $25{ }^{\circ} \mathrm{C}$, respectively) were 
458

459

460

461

462

463

464

465

466

467

468

469

470

471

472

473

474

475

476

477

478

479

480

481

482

483

484

considerably higher than those measured by Zhou et al. (2018) in flooded rice $\left(6 \mathrm{~kg} \mathrm{~N}_{2} \mathrm{O}-\mathrm{N} \mathrm{ha}{ }^{-1}\right.$ $\mathrm{yr}^{-1}$ ), and than those calculated in field experiments with winter wheat fertilized with $190 \mathrm{~kg} \mathrm{~N}$ ha $^{-1}$ as digestate $\left(0.7 \mathrm{~kg} \mathrm{~N}_{2} \mathrm{O}-\mathrm{N} \mathrm{ha}^{-1}\right)$ on the same soil (Sánchez-Rodríguez et al., 2018a).

Field experiments monitoring extreme flood events are necessary to check if extreme flood events can cause similar or higher GHG emissions than those produced from agricultural management events (e.g. fertilizer addition, tillage). However, monitoring emissions during real extreme flood events remains highly challenging as they are notoriously difficult to predict, it is problematic to logistically deploy GHG equipment, and they frequently lack a counterfactual control treatment. In view of the potential GHG emissions reported here under flooding and the large land surfaces that are affected by these extreme floods (Klaus et al., 2016; Met Office, 2014), there is an urgent need to produce more accurate GHG emission estimates from these events. This will be useful to help explain differences between top-down and bottom-up GHG emission calculations as well as seasonal patterns in observed atmospheric concentrations (Ganesan et al., 2015), and to aid the design of more sustainable GHG mitigation strategies. It should also be considered that the gaseous loss of $\mathrm{NH}_{3}$ in particular both during and after flooding not only affects soil functioning but also negatively impacts on air quality and should be considered further (Galloway et al., 2003).

Finally, these losses of nutrients via gaseous emissions also alter soil functions such as habitat provision, element, water and organic matter cycling that are essential for essential soilbased ecosystem services, i.e. biomass production, biodiversity conservation, water quality and supply and climate regulation. Consequently, agricultural management and practices in locations where there is a high risk of flooding (historically or in recent years) should be more focused on maintaining these soil functions with fertilizer and organic matter applications, particularly after extreme flood events. If possible, they should improve the drainage and the water evacuation facilities (e.g. water pumping stations) to minimize the time that the floodwater remains on the land. 


\subsection{Habitat provision for soil organisms: Soil microbial communities and their relationship with} environmental factors

As used in previous studies, PLFA analysis was used to provide a broad scale assessment of changes in soil microbial communities induced by flooding (Bossio and Scow, 1998; Liao et al., 2018; Pan et al., 2016). Although PLFA groups cannot be quantitatively compared against each other (e.g. fungal biomass vs Gram+ biomass), they do provide a relative indication of how experimental treatment affects each group. Overall, extreme flooding caused a reduction in total microbial biomass, particularly at higher temperatures. During flooding it was expected that the microbial biomass would increase at $25^{\circ} \mathrm{C}$ in response to the death of the vegetation and a large input of labile $\mathrm{C}$ to the soil. However, our results strongly suggest that maintaining live roots and an active rhizosphere is more important for preserving the microbial community. This is particularly true for obligate biotrophs such as arbuscular mycorrhizal fungi (AM fungi). Poor plant growth in the recovery phase might also explain why the microbial biomass and AM fungal biomass did not recover in the $25^{\circ} \mathrm{C}$ flooded treatment, even when $\mathrm{O}_{2}$ was restored to the system.

Flooding also induced a very large reduction in total fungal biomass relative to other taxonomic groups (by $>50 \%$ at 15 and $25{ }^{\circ} \mathrm{C}$ ). With a few exceptions, these fungi are almost all obligate aerobes (Tonouchi, 2009), consequently it is not surprising that their loss is induced by long-term flooding and anoxia. This sensitivity of fungi to waterlogging suggests that this metric may provide a good indicator of flood stress within the microbial community.

Gram+ bacteria are typically considered to be more resistant to stress (Guckert et al., 1985 ) and were shown to increase in response to flooding in a previous study (Bossio and Scow, 1998). We found a similar effect during flooding, however, this effect did not persist after the soil recovery phase. In contrast, the actinomycetes, a filamentous subset of the Gram+ bacteria, were found to decrease in response to flooding. Similar to fungi, we ascribe this response to their obligate aerobic nature. Gram- bacteria are generally considered to be fast growing in comparison to Gram+ bacteria. It is possible that the small increase in their population upon flood removal was due to them filling the niche space left by fungi in the soil. 
513 communities in this grassland soil and the importance in providing soil-based ecosystem services

514 (biomass production, biodiversity conservation, water quality and supply and climate regulation).

515 The use of flood-resistant plant species would help maintain the delivery of these ecosystem

516 services in flood prone areas. Lastly, the persistent alterations in microbial community seen even after flood recovery also indicate that soil biological indicators are more sensitive than most routine chemical indicators.

\section{Conclusions}

In this study, we show that extreme flood events negatively impact upon soil functioning and soil-based ecosystem services, and water quality of an intact grassland soil, with the damage being more severe at higher temperatures. Clear alterations in element cycling and dynamics, biomass production and GHG emissions were produced in the short-term and biological alterations (biological population regulation, microbial biomass and structure of soil microbial communities) in the mid-term. This mesocosm experiment provides clear evidence that ecosystem responses to extreme weather events are highly dependent on temperature. It is predicted that extreme events of different types are likely to become more frequent in the future and consequently, extreme events may occur in close succession (e.g. flood followed by drought). Further work, including mechanistic (simulating conditions of the different seasons) and field (different seasons) experiments, is therefore required to determine how flooding alters the resilience of grasslands to future extreme weather events.

\section{Acknowledgments}

This work was supported by the Project 'Legacy effects of the extreme flood events on soil quality and ecosystem functioning', NERC Grant Reference NE/M005143/1, by the UK

537 Department for Environment, Food and Rural Affairs (DEFRA) project LM0316, by the UK

538 Natural Environment Research Council (NE/I012303/1) and the Sêr Cymru LCEE-NRN project, 539 Climate-Smart Grass. Sánchez-Rodríguez also acknowledges funding support by the 'Fundación 
540 Ramón Areces' for his postdoctoral scholarship “Beca para ampliación de estudios en el

541 extranjero en materia de Ciencias de la Vida y de la Materia" and the contract "Juan de la Cierva-

542 Incorporación (IJCI-2016-27388)" of the Spanish Ministry of Science, Innovation and

543 Universities.

References

546 Alongi, D.M., de Carvalho, N.A., Amaral, A.L., da Costa, A., Trott, L., Tirendi, F., 2012.

547 Uncoupled Surface and below-ground soil respiration in mangroves: implications for estimates of dissolved inorganic carbon export. Biogeochemistry 109, 151-162.

Bartelt-Ryser, J., Joshi, J., Schmid, B., Brandl, H., Balser, T., 2005. Soil feedbacks of plant diversity on soil microbial communities and subsequent plant growth. Perspectives in Plant Ecology, Evolution and Systematics 7, 27-49.

Bateman, E.J., Baggs, E.M., 2005. Contributions of nitrification and denitrification to N2O emissions from soils at different water-filled pore space. Biology and Fertility of Soils 41,

Bedard, C., Knowles, R., 1989. Physiology, biochemistry, and specific inhibitors of $\mathrm{CH}_{4}, \mathrm{NH}_{4}^{+}$, and $\mathrm{CO}$ oxidation by methanotrophs and nitrifiers. Microbiology Reviews 53, 68-84.

Blagodatsky, S.A., Heinemeyer, O., Richter, J., 2000. Estimating the active and total soil microbial biomass by kinetic respiration analysis. Biology and Fertility of Soils 32, 7381.Bossio, D.A., Scow, K.M., 1998. Impacts of carbon and flooding on soil microbial communities: phospholipid fatty acid profiles and substrate utilization patterns. Microbial Ecology 35, 265-278.

Bowman, J.P., Skerratt, J.H., Nichols, P.D., Sly, L.I., 1991. Phospholipid fatty-acid and lipopolysaccharide fatty-acid signature lipids in methane-utilizing bacteria. FEMS Microbiology Ecology 85, 15-22.

Bowman, J.P., Sly, L.I., Nichols, P.D., Hayward, A.C., 1993. Revised taxonomy of the methanotrophs: Description of Methylobacter gen. nov., emendation of Methylococcus, validation of Methylosinus and Methylocystis species, and a proposal that the family 
Methylococcaceae includes only the Group I methanotrophs. International Journal of Systematic Bacteriology 43, 735-753.

Bünemann, E.K., Bongiorno, G., Bai, Z., Creamer, R.E., de Deyn, G., de Goede R., Fleskens, L., Geissen, V., Kuyper, T.W., Mäder, P., Pulleman, M., Sukkel, W., van Groenigen, J.W., Brussaard, L., 2018. Soil quality - A critical review. Soil Biology and Biochemistry 120, $105-125$.

Castro, H.F., Classen, A.T., Austin, E.E., Norby, R.J., Schadt, C.W., 2010. Soil Microbial Community Responses to Multiple Experimental Climate Change Drivers. Applied and Environmental Microbiology 76, 999-1007.

Chen, A., Lei, B., Hu, W., Lu, Y., Mao, Y., Duan, Z., Shi, Z., 2015. Characteristics of ammonia volatilization on rice grown under different nitrogen application rates and its quantitative predictions in Erhai Lake Watershed, China. Nutrient Cycling in Agroecosystems 101, $139-152$.

Das, K.K., Panda, D., Sarkar, R.K., Reddy, J.N., Ismail, A.M., 2009. Submergence tolerance in relation to variable floodwater conditions in rice. Environmental and Experimental Botany $66,425-434$.

Ganesan, A. L., Manning, A. J., Grant, A., Young, D., Oram, D. E., Sturges, W. T., Moncrieff, J. B., O'Doherty, S., 2015. Quantifying methane and nitrous oxide emissions from the UK and Ireland using a national-scale monitoring network. Atmospheric Chemistry and Physics 15, 6393-6406.

Galloway, J. N., Aber, J. D., Erisman, J. W., Seitzinger, S. P., Howarth, R. W., Cowling, E. B., Cosby, B.J., 2003. The nitrogen cascade. Bioscience 53, 341-356.

Glaz, B., Lingle, S.E., 2012. Flood duration and time of flood onset effects on recently planted sugarcane. Agronomy Journal 104, 575-583.

Guckert, J.B., Antworth, C.P., Nichols, P.D., White, D.C., 1985. Phospholipid, ester-linked fatty acid profiles as reproducible assays for changes in prokaryotic community structure of estuarine sediments. FEMS Microbiology Ecology 1, 147-158. 
595

596

597

598

599

600

601

602

603

604

605

606

607

608

609

610

611

612

613

614

615

616

617

618

619

620

621

Hirsch, P.R., Jhurreea, D., Williams, J.K., Murray, P.J., Scott, T., Misselbrook, T.H., Goulding, K.W.T., Clark, I.M., 2017. Soil resilience and recovery: rapid community responses to management changes. Plant and Soil 4, 283-297.

Hou, A.X., Chen, G.X., Wang, Z.P., Van Cleemput, O., Patrick Jr., W.H., 2000. Methane and nitrous oxide emissions from a rice field in relation to soil redox and microbiological processes. Soil Science Society of America Journal 64, 2180-2186.

IPCC, 2013. Climate Change 2013: The Physical Science Basis. Contribution of Working Group I to the Fifth Assessment Report of the Intergovernmental Panel on Climate Change. Stocker, T.F., Qin, D., Plattner, G.K., Tignor, M., Allen, S.K., Boschung, J., Nauels, A., Xia, Y., Bex, V., Midgley, P.M. (Eds.). Cambridge University Press, Cambridge, United Kingdom and New York, NY, USA, 1535 pp.

IPCC, 2014. Managing the risks of extreme events and disasters to advance climate change adaptation. In: Field, C.B., Barros, V., Stocker, T.F., Qin, D., Dokken, D.J., Ebi, K.L., Mastrandrea, M.D., Mach, K.J., Plattner, G.K., Allen, S.K., Tignor, M., Midgley, P.M. (Eds.), A Special Report of Working Groups I and II of the Intergovernmental Panel on Climate Change. Cambridge university Press, Cambridge, UK, and New York, NY, USA (p. 582).

IUSS Working Group WRB, 2015. World Reference Base for Soil Resources 2014, update 2015. International soil classification system for naming soils and creating legends for soil maps. World Soil Resources Reports No. 106. FAO, Rome.

Jones, D.L., Nguyen, C., Finlay, R.D., 2009. Carbon flow in the rhizosphere: carbon trading at the soil-root interface. Plant and Soil 321, 5-33.

Jones, D.L., Shannon, D., Murphy, D.V., Farrar, J., 2004. Role of dissolved organic nitrogen (DON) in soil N cycling in grassland soils. Soil Biology and Biochemistry 36, 749-756.

Kieft, T.L., Ringelberg, D.B., White, D.C., 1994. Changes in ester linked phospholipid fatty acid profiles of subsurface bacteria during starvation and desiccation in a porous medium. Applied and Environmental Microbiology 60, 3292-3299. 
622

623

624

625

626

627

628

629

630

631

632

633

634

635

636

637

638

639

640

641

642

643

644

645

646

647

Kirwan, M.L., Blum, L.K., 2011. Enhanced decomposition offsets enhanced productivity and soil carbon accumulation in coastal wetlands responding to climate change. Biogeosciences 8 , 987-993.

Klaus, S., Kreibich, H., Merz, B., Kuhlmann, B., Schröter, K., 2016. Environmental Earth Sciences 75: 1289.

Lewis, D.B., Brown, J.A., Jimenes, K.L., Effects of flooding and warming on soil organic matter mineralization in Avicennia germinans mangrove forests and Juncus roemerianus salt marshes. Estuarine, Coastal and Shelf Science 139, 11-19.

Liao, H.K., Chapman, S.J., Li, Y.Y., Yao, H.Y., 2018. Dynamics of microbial biomass and community composition after short-term water status change in Chinese paddy soils. Environmental Science and Pollution Research 25, 2932-2941.

Loeppert, R.H. Inskeep, W.P., 1996. Iron. In: Sparks DL (Ed.), Methods of Soil Analysis. Part 3. Chemical Methods. ASA/SSSA, Madison, WI, pp. 639-664.

Mackenzie, A.F., Fan, M.S., Cadrin, F., 1998. Nitrous oxide emission in three years as affected by tillage, corn-soybean-alfalfa rotations, and nitrogen fertilization. Journal of Environmental Quality 27, 698-703.

Met Office, 2014. The Recent Storms and Floods in the UK. Available at: http://nora.nerc.ac.uk/id/eprint/505192/1/N505192CR.pdf

Millaleo, R., Reyes-Díaz, M., Ivanov, A.G., Mora, M.L., Alberdi, M., 2010. Manganese as essential and toxic element for plants: transport, accumulation and resistance mechanisms. Journal of Soil Science and Plant Nutrition 10, 476-494.

Miller, W.D., Neubauer, S.C., Anderson, I.C., 2001. Effects of sea level induced disturbances on high salt marsh metabolism. Estuaries 24, 357-367.

Milroy, S.P., Bange, M.P., 2013. Reduction in radiation use efficiency of cotton (Gossypium hirsutum L.) under repeated transient waterlogging in the field. Field Crops Research 140, $51-58$. 
Miranda, K.M, Espey, M.G., Wink, D.A., 2001. A rapid simple spectrophotometric method for simultaneous detection of nitrate and nitrite. Nitric Oxide: Biology and Chemistry 5, 6271.

Morris, J., Brewin, P., 2014. The impact of seasonal flooding on agriculture: the spring 2012 floods in Somerset, England. Journal of Flood Risk Management 7, 128-140.

Mulvaney, R.L., 1996. Nitrogen - inorganic forms. In: Sparks, D.L. (Ed.), Methods of Soil Analysis. Part 3. Chemical Methods. Soil Science Society of America, Madison, WI, pp. $1123-1184$.

Murphy, J., Riley, J.P., 1962. A modified single solution method for the determination of phosphate in natural waters. Analytica Chimica Acta 27, 31-36.

Nielsen, T.H., Nielsen, L.P., Revsbech, N.P., 1996. Nitrification and coupled nitrificationdenitrification associated with a soil-manure interface. Soil Science Society of America Journal 60, 1829-1840.

Niklaus, P.A., Alphei, J., Ebersberger, D., Kampichler, D., Kandeler, E., Tscherko, D., 2003. Six years of in situ $\mathrm{CO}_{2}$ enrichment evoke changes in soil structure and soil biota of nutrientpoor grassland. Global Change Biology 9, 585-600.

Niu, S., Luo, Y., Li, D., Cao, S., Xia, J., Smith, M.D., 2014. Plant growth and mortality under climatic extremes: an overview. Environmental and Experimental Botany 98, 13-19.

Oksanen, J., Blanchet, F.G., Friendly, M., Kindt, R., Legendre, P., McGlinn, D., Minchin, P.R., O'Hara, R.B., Simpson, G.L., Solymos, P., Henry, M., Stevens, H., Szoecs, E., Wagner, H., 2018. Vegan: Community Ecology Package. R package version 2.5-2. https://CRAN.Rproject.org/package $=$ vegan

Olsson, P.A., Thingstrup, I., Jakobsen, I., Baath, F., 1999. Estimation of the biomass of arbuscular mycorrhizal fungi in a linseed field. Soil Biology and Biochemistry 31, 1879-1887.

Osanai, Y., Tissue, D.T., Bange, M.P., Braunack, M.V., Anderson, I.C., Singh, B.K., 2017. Interactive effects of elevated $\mathrm{CO}_{2}$, temperature and extreme weather events on soil nitrogen and cotton production under future climate regimes. Agriculture, Ecosystems and Environment 246, 343-353. 
Pan, F.X., Li, Y.Y., Chapman, S.J., Yao, H.Y., 2016. Effect of rice straw application on microbial community and activity in paddy soil under different water status. Environmental Science and Pollution Research 23, 5941-5948.

Paul, E.A., Clark, F.E., 1996. Soil Microbiology and Biochemistry. Academic Press, San Diego, CA.

Posthumus, H., Morris, J., Hess, T.M., Neville, D., Phillips, E., Baylis, A., 2009. Impacts of the summer 2007 floods on agriculture in England. Journal of Flood Risk Management 2, 182 189.

R Core Team, 2013. R: A language and environment for statistical computing. R Foundation for Statistical Computing, Vienna, Austria. URL http://www.R-project.org/.

Ratledge, C., Wilkinson, S.G., 1988. Microbial Lipids. Academic Press, London.

Reddy, K.R., Patrick Jr, W.H., 1975. Effect of alternate aerobic and anaerobic conditions on redox potential, organic matter decomposition and nitrogen loss in a flooded soil. Soil Biology and Biochemistry 7, 87-94.

Romanescu, G., Stoleriu, C.C., 2017. Exceptional floods in the Prust basin, Romania, in the context of heavy rains in the summer of 2010. Natural Hazards and Earth Systems Sciences $17,381-396$.

Sánchez-Rodríguez, A.R., Hill, P.W., Chadwick, D.R., Jones, D.L., 2017. Crop residues exacerbate the negative effects of extreme flooding on soil quality. Biology and Fertility of Soils 53, 751-765.

Sánchez-Rodríguez, A.R., Hill, P.W., Chadwick, D.R., Jones, D.L., 2019. Typology of extreme flood event leads to differential impacts on soil quality. Soil Biology and Biochemistry $129,153-168$.

Sánchez-Rodríguez, A.R., Carswell, A.M., Shaw, R., Hunt, J., Saunders, K., Cotton, J., Chadwick D.R., Jones, D.L., Misselbrook, T.H., 2018a. Advanced Processing of Food Waste Based Digestate for Mitigating Nitrogen Losses in a Winter Wheat Crop. Frontiers in Sustainable Food Systems 2:35. 
703

704

705

706

707

708

709

710

711

712

713

714

715

716

717

718

719

720

721

722

723

724

725

726

727

728

729

730

Sánchez-Rodríguez, A.R., Chadwick, D.R., Tatton, G.S., Hill, P.W., Jones DL, 2018b. Comparative effects of prolonged freshwater and saline flooding on nitrogen cycling in an agricultural soil. Applied Soil Ecology 125, 56-70.

Senbayram, M., Chen, R., Budai, A., Bakken, L., Dittert, K., 2012. $\mathrm{N}_{2} \mathrm{O}$ emission and the $\mathrm{N}_{2} \mathrm{O} /\left(\mathrm{N}_{2} \mathrm{O}+\mathrm{N}_{2}\right)$ product ratio of denitrification as controlled by available carbon substrates and nitrate concentrations. Agriculture, Ecosystems and Environment 147, 4-12.

Shao, G.C., Lan, J.J., Yu, S.E., Liu, N., Guo, R.Q., She, D.L., 2013. Photosynthesis and growth of winter wheat in response to waterlogging at different growth stages. Photosynthetica 51, $429-437$.

Slater, L.J., Villarini, G., 2016. Recent trends in US flood risk. Geophysical Research Letters 43, $12428-12436$.

Thorne, C., 2014. Geographies of UK Flooding in 2013/4. Geographical Journal 180, 297-309.

Tonouchi, A., 2009. Isolation and characterization of a novel facultative anaerobic filamentous fungus from Japanese rice field Soil. International Journal of Microbiology 2009:571383.

Trenberth, K. E., 2011. Changes in precipitation with climate change. Climate Research 47, $123-$ 138.

Xu, X., Ran, Y., Li, Y., Zhang, Q., Liu, Y., Pan, H., Guan, X., Li, J., Shi, J., Dong, Li, Li, Z., Di, H., Xu, J., 2016. Warmer and drier conditions alter the nitrifier and denitrifier communities and reduce $\mathrm{N}_{2} \mathrm{O}$ emissions in fertilized vegetable soils. Agriculture, Ecosystems and Environment 231, 133-142.

Zelles, L., 1999. Fatty acids patterns of phospholipids and lipopolysaccharides in the characterization of microbial communities in soil: a review. Biology and Fertility of Soils $29,111-129$.

Zhou, M., Wang, X., Wang, Y., Zhu, B., 2018. A three-year experiment of annual methane and nitrous oxide emissions from the subtropical permanently flooded rice paddy fields of China: Emission factor, temperature sensitivity and fertilizer nitrogen effect. Agricultural and Forest Meteorology 250-251, 299-307. 
731

732

733

734

735

736

737

738

739

740

741

742

743

744

745

746

747

748

749

750

751

752

753

754

755

\section{Figure captions}

Fig. 1 Time course (mean value and standard error) of $\mathrm{pH}, \mathrm{P}$ and $\mathrm{Fe}$ in soil solution and floodwater for the different treatments. 5C: unflooded mesocosms at $5{ }^{\circ} \mathrm{C} ; 15 \mathrm{C}$ : unflooded mesocosms at $15{ }^{\circ} \mathrm{C}$; $25 \mathrm{C}$ : unflooded mesocosms at $25{ }^{\circ} \mathrm{C}$; $5 \mathrm{~F}$ : flooded mesocosms at $5{ }^{\circ} \mathrm{C} ; 15 \mathrm{~F}$ : flooded mesocosms at $15{ }^{\circ} \mathrm{C} ; 25 \mathrm{~F}$ : flooded mesocosms at 25 ${ }^{\circ} \mathrm{C}$. Four replicates per treatment.

Fig. 2 Time course (mean value and standard error) of $\mathrm{NH}_{4}{ }^{+}$and $\mathrm{NO}_{3}{ }^{-}$in soil solution and floodwater for the different treatments. 5C: unflooded mesocosms at $5{ }^{\circ} \mathrm{C} ; 15 \mathrm{C}$ : unflooded mesocosms at $15{ }^{\circ} \mathrm{C}$; 25C: unflooded mesocosms at $25{ }^{\circ} \mathrm{C}$; 5F: flooded mesocosms at $5{ }^{\circ} \mathrm{C} ; 15 \mathrm{~F}$ : flooded mesocosms at $15{ }^{\circ} \mathrm{C} ; 25 \mathrm{~F}$ : flooded mesocosms at 25 ${ }^{\circ} \mathrm{C}$. Four replicates per treatment.

Fig. 3 Daily $\mathrm{CH}_{4}, \mathrm{CO}_{2}$ and $\mathrm{N}_{2} \mathrm{O}$ fluxes and apparent $\mathrm{NH}_{3}$ volatilization (mean value and standard error). $5 \mathrm{C}$ : unflooded mesocosms at $5^{\circ} \mathrm{C} ; 15 \mathrm{C}$ : unflooded mesocosms at $15^{\circ} \mathrm{C}$; 25C: unflooded mesocosms at $25{ }^{\circ} \mathrm{C}$; $5 \mathrm{~F}$ : flooded mesocosms at $5{ }^{\circ} \mathrm{C}$; $15 \mathrm{~F}$ : flooded mesocosms at $15^{\circ} \mathrm{C} ; 25 \mathrm{~F}$ : flooded mesocosms at $25^{\circ} \mathrm{C}$. Four replicates per treatment.

Fig. 4 Principal component analysis (PCA) of microbial community PLFAs in response to flooding and temperature. a Relationships between taxonomic groups (arrows) that were used for the PCA and environmental variables (small crosses; $\mathrm{pH}, \mathrm{P}, \mathrm{Fe}, \mathrm{NH}_{4}{ }^{+}$, $\mathrm{NO}_{3}{ }^{-}$, daily $\mathrm{CH}_{4}, \mathrm{CO}_{2}$ and $\mathrm{N}_{2} \mathrm{O}$ fluxes); b Treatment separation after the flood phase; and c Treatment separation after soil recovery. $5 \mathrm{C}$ : unflooded mesocosms at $5{ }^{\circ} \mathrm{C}$; $15 \mathrm{C}$ : unflooded mesocosms at $15{ }^{\circ} \mathrm{C}$; 25C: unflooded mesocosms at $25^{\circ} \mathrm{C}$; 5F: flooded mesocosms at $5{ }^{\circ} \mathrm{C} ; 15 \mathrm{~F}$ : flooded mesocosms at $15{ }^{\circ} \mathrm{C} ; 25 \mathrm{~F}$ : flooded mesocosms at 25 ${ }^{\circ} \mathrm{C}$. Four replicates per treatment.

Fig. 5 Biomass production at the end of the experiment (mean value and standard error). Different letter indicate differences according to Tukey's HSD test at a probability level 
756 of 0.05 . 5C: unflooded mesocosms at $5{ }^{\circ} \mathrm{C} ; 15 \mathrm{C}$ : unflooded mesocosms at $15{ }^{\circ} \mathrm{C} ; 25 \mathrm{C}$ :

757 unflooded mesocosms at $25^{\circ} \mathrm{C} ; 5 \mathrm{~F}$ : flooded mesocosms at $5{ }^{\circ} \mathrm{C} ; 15 \mathrm{~F}$ : flooded mesocosms

758 at $15{ }^{\circ} \mathrm{C} ; 25 \mathrm{~F}$ : flooded mesocosms at $25^{\circ} \mathrm{C}$. Four replicates per treatment. 


\section{Highlights}

- Flooding induced a rapid release of nutrients, especially at higher temperatures.

- $700 \mathrm{~kg} \mathrm{CH}_{4}-\mathrm{C} \mathrm{ha}^{-1}$ and $5 \mathrm{~kg} \mathrm{NH}_{3}-\mathrm{N} \mathrm{ha}^{-1}$ were released in the flood phase at 25 ${ }^{\circ} \mathrm{C}$.

- During soil recovery, nitrification led to $1.0-14.2 \mathrm{~kg} \mathrm{~N}_{2} \mathrm{O}-\mathrm{N} \mathrm{ha}^{-1}$ losses at 5-25 ${ }^{\circ} \mathrm{C}$.

- Flooding reduced soil microbial biomass, actinomycetes and arbuscular mycorrhiza.

- Flooding reduced biomass production by $18 \%$ at $5{ }^{\circ} \mathrm{C}, 50 \%$ at $15{ }^{\circ} \mathrm{C}$ and $95 \%$ at $25^{\circ} \mathrm{C}$. 
Soil Solution
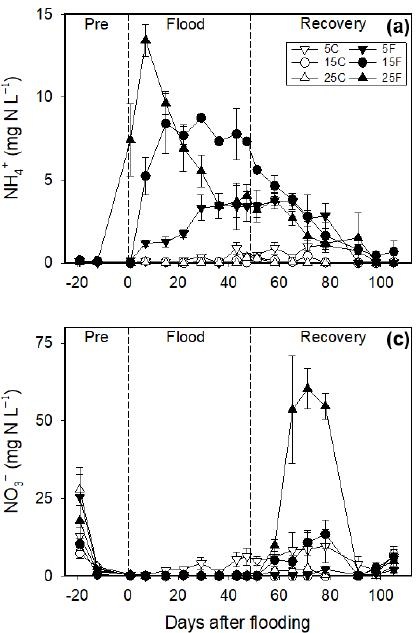

Floodwater
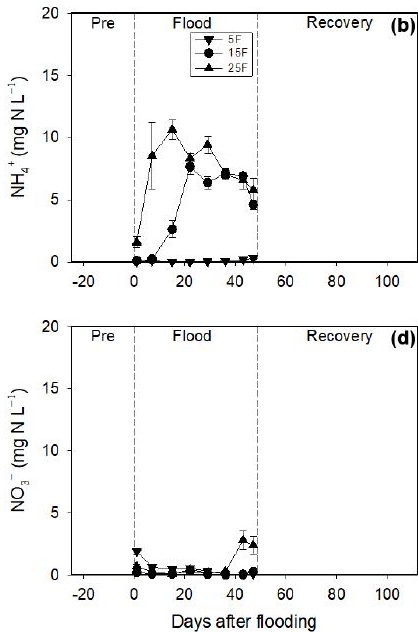
Taxonomic groups and environmental variables

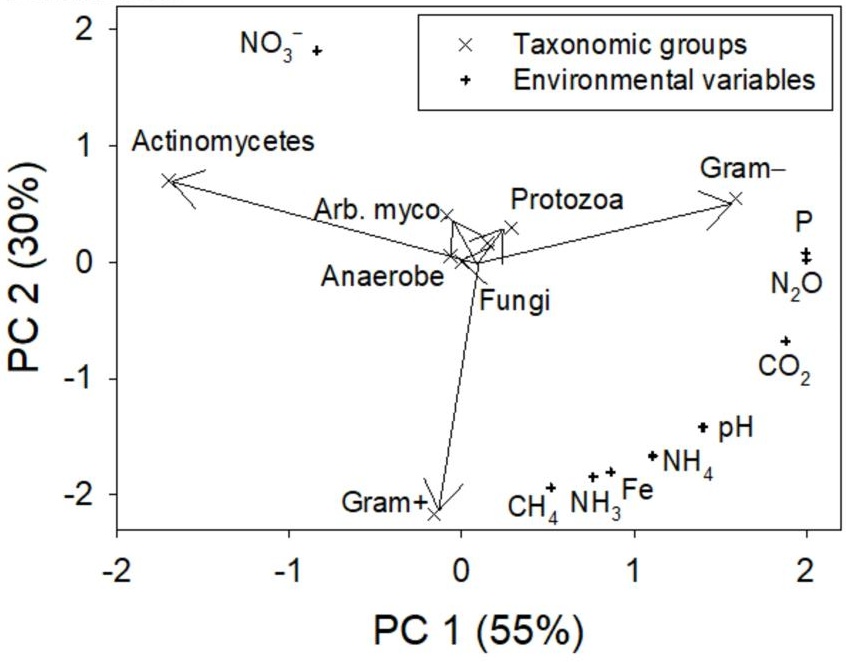

\section{After the flood phase}

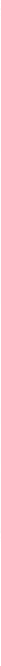

\section{After the soil recovery}

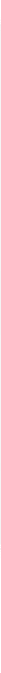



Table 1 Potential losses of nutrients (mean \pm standard error, $n=4$ ) as a function of temperature and flooding. Different letters indicate differences according to Tukey's HSD test at a probability level of 0.05 .

\begin{tabular}{lllll}
\hline Treatment & $\begin{array}{l}\mathrm{P} \\
\left(\mathrm{kg} \mathrm{P} \mathrm{ha}^{-1}\right)\end{array}$ & $\begin{array}{l}\mathrm{Fe} \\
\left(\mathrm{kg} \mathrm{Fe} \mathrm{ha}^{-1}\right)\end{array}$ & $\begin{array}{l}\mathrm{NH}_{4}^{+} \\
\left(\mathrm{kg} \mathrm{N} \mathrm{ha}^{-1}\right)\end{array}$ & $\begin{array}{l}\mathrm{NO}_{3}^{-} \\
\left(\mathrm{kg} \mathrm{N} \mathrm{ha}^{-1}\right)\end{array}$ \\
\hline Control $5^{\circ} \mathrm{C}$ & $1.9 \pm 0.1 \mathrm{c}$ & $0.4 \pm 0.1 \mathrm{~d}$ & $0.4 \pm 0.1 \mathrm{~d}$ & $3.6 \pm 1.0 \mathrm{a}$ \\
Control $15^{\circ} \mathrm{C}$ & $1.9 \pm 0.1 \mathrm{c}$ & $0.0 \pm 0.0 \mathrm{~d}$ & $0.1 \pm 0.0 \mathrm{~d}$ & $0.2 \pm 0.0 \mathrm{~b}$ \\
Control $25^{\circ} \mathrm{C}$ & $1.9 \pm 0.2 \mathrm{c}$ & $0.1 \pm 0.0 \mathrm{~d}$ & $0.1 \pm 0.0 \mathrm{~d}$ & $0.2 \pm 0.1 \mathrm{~b}$ \\
Flood $5^{\circ} \mathrm{C}$ & $5.0 \pm 0.2 \mathrm{~b}$ & $3.9 \pm 0.6 \mathrm{c}$ & $2.4 \pm 0.4 \mathrm{c}$ & $2.0 \pm 0.2 \mathrm{ab}$ \\
Flood $15^{\circ} \mathrm{C}$ & $8.5 \pm 0.4 \mathrm{a}$ & $10.6 \pm 0.4 \mathrm{~b}$ & $12.5 \pm 0.2 \mathrm{~b}$ & $0.5 \pm 0.1 \mathrm{~b}$ \\
Flood $25^{\circ} \mathrm{C}$ & $9.6 \pm 0.7 \mathrm{a}$ & $13.7 \pm 1.3 \mathrm{a}$ & $17.3 \pm 1.0 \mathrm{a}$ & $3.6 \pm 0.7 \mathrm{a}$ \\
$P$ value & $<\mathbf{0 . 0 0 1}$ & $<\mathbf{0 . 0 0 1}$ & $<\mathbf{0 . 0 0 1}$ & $<\mathbf{0 . 0 0 1}$ \\
\hline
\end{tabular}


Table 2 Cumulative GHG fluxes, global warming potential (GWP in equivalent $\mathrm{kg}$ of $\mathrm{CO}_{2}$ ) and apparent $\mathrm{NH}_{3}$ volatilization (mean \pm standard error, $n=4$ ) as a function of temperature and flooding. Different letters indicate differences according to Tukey's HSD test at a probability level of 0.05 .

\begin{tabular}{|c|c|c|c|c|c|c|}
\hline Treatment & $\begin{array}{l}\mathrm{CH}_{4} \\
\left(\mathrm{~kg} \mathrm{C} \mathrm{ha}^{-1}\right)\end{array}$ & $\begin{array}{l}\mathrm{CO}_{2} \\
\left(\mathrm{~kg} \mathrm{C} \mathrm{ha}^{-1}\right)\end{array}$ & $\begin{array}{l}\mathrm{N}_{2} \mathrm{O} \\
\left(\mathrm{kg} \mathrm{N} \mathrm{ha}^{-1}\right)\end{array}$ & $\begin{array}{l}\text { GWP } \\
\left(\mathrm{kg} \mathrm{C} \mathrm{ha}^{-1}\right)\end{array}$ & $\begin{array}{l}\text { GWP* } \\
\left(\mathrm{kg} \mathrm{C} \mathrm{ha-1)}^{-1}\right)\end{array}$ & $\begin{array}{l}\text { Apparent } \mathrm{NH}_{3} \\
\left(\mathrm{~kg} \mathrm{~N} \mathrm{ha}^{-1}\right)\end{array}$ \\
\hline Control $5^{\circ} \mathrm{C}$ & $0.5 \pm 0.6 \mathrm{c}$ & $421 \pm 79 b$ & $0.6 \pm 0.2 \mathrm{~cd}$ & $614 \pm 51 b$ & $192 \pm 66 b$ & $0.1 \pm 0.0 \mathrm{c}$ \\
\hline Control $15^{\circ} \mathrm{C}$ & $0.8 \pm 0.8 \mathrm{c}$ & $-73 \pm 65 c$ & $0.0 \pm 0.2 \mathrm{~d}$ & $-33 \pm 83 b$ & $41 \pm 43 b$ & $0.1 \pm 0.0 \mathrm{c}$ \\
\hline Control $25^{\circ} \mathrm{C}$ & $-0.2 \pm 0.5 \mathrm{c}$ & $-289 \pm 60 c$ & $-0.1 \pm 0.1 \mathrm{~d}$ & $-311 \pm 94 b$ & $-22 \pm 45 b$ & $0.1 \pm 0.0 \mathrm{c}$ \\
\hline Flood $5^{\circ} \mathrm{C}$ & $0.3 \pm 0.2 \mathrm{c}$ & $595 \pm 74 b$ & $1.0 \pm 0.1 \mathrm{c}$ & $896 \pm 116 b$ & $301 \pm 49 b$ & $0.1 \pm 0.0 \mathrm{c}$ \\
\hline Flood $15^{\circ} \mathrm{C}$ & $45.7 \pm 5.2 \mathrm{~b}$ & $453 \pm 88 b$ & $5.7 \pm 1.4 \mathrm{~b}$ & $3713 \pm 519 b$ & $3261 \pm 435 b$ & $1.0 \pm 0.9 \mathrm{~b}$ \\
\hline Flood $25^{\circ} \mathrm{C}$ & $717.7 \pm 75.5 \mathrm{a}$ & $1196 \pm 102 \mathrm{a}$ & $14.2 \pm 1.9 \mathrm{a}$ & $29817 \pm 2162 \mathrm{a}$ & $28621 \pm 2267 \mathrm{a}$ & $5.0 \pm 0.2 \mathrm{a}$ \\
\hline$P$ value & $<0.001$ & $<0.001$ & $<0.001$ & $<0.001$ & $<0.001$ & $<0.001$ \\
\hline
\end{tabular}


Table 3 ANOVA of soil microbial biomass (total amount of PLFAs, $\mathrm{nmol} \mathrm{g}^{-1}$ ) and taxonomic groups (\%) at the end of the flood phase and after floodwater removal and soil recovery (mean \pm standard error, $n=4$ ). Different letters indicate differences according to Tukey's HSD test at a probability level of 0.05 .

\begin{tabular}{|c|c|c|c|c|c|c|c|c|}
\hline Treatment & $\begin{array}{l}\text { Microbial } \\
\text { biomass } \\
\left(\mathrm{nmol} \mathrm{g}^{-1}\right)\end{array}$ & $\begin{array}{l}\text { Gram+ } \\
\text { bacteria } \\
(\%)\end{array}$ & $\begin{array}{l}\text { Gram- } \\
\text { bacteria } \\
(\%)\end{array}$ & $\begin{array}{l}\text { Actinomycetes } \\
(\%)\end{array}$ & $\begin{array}{l}\text { Anaerobes } \\
(\%)\end{array}$ & $\begin{array}{l}\text { Protozoa } \\
(\%)\end{array}$ & $\begin{array}{l}\text { Arb. myco. } \\
(\%)\end{array}$ & $\begin{array}{l}\text { Fungi } \\
(\%)\end{array}$ \\
\hline \multicolumn{9}{|c|}{ At the end of flooding } \\
\hline Control $5^{\circ} \mathrm{C}$ & $379.5 \pm 32.9 \mathrm{a}$ & $24.3 \pm 0.2 \mathrm{c}$ & $49.6 \pm 0.2$ & $14.2 \pm 0.4 \mathrm{ab}$ & $1.61 \pm 0.09$ & $2.17 \pm 0.12$ & $6.36 \pm 0.13 \mathrm{a}$ & $1.85 \pm 0.39 \mathrm{ab}$ \\
\hline Control $15^{\circ} \mathrm{C}$ & $339.1 \pm 17.5 \mathrm{a}$ & $25.6 \pm 1.3 \mathrm{bc}$ & $48.3 \pm 1.1$ & $14.6 \pm 0.5 \mathrm{ab}$ & $1.64 \pm 0.15$ & $2.18 \pm 0.34$ & $5.70 \pm 0.23 \mathrm{ab}$ & $2.00 \pm 0.16 \mathrm{a}$ \\
\hline Control $25^{\circ} \mathrm{C}$ & $311.9 \pm 8.2 \mathrm{a}$ & $27.1 \pm 0.2 \mathrm{~b}$ & $47.0 \pm 0.5$ & $16.3 \pm 0.4 \mathrm{a}$ & $1.55 \pm 0.16$ & $2.00 \pm 0.08$ & $4.95 \pm 0.14 \mathrm{bc}$ & $1.15 \pm 0.23 \mathrm{abc}$ \\
\hline Flood $5^{\circ} \mathrm{C}$ & $378.9 \pm 23.3 \mathrm{a}$ & $26.5 \pm 0.2 \mathrm{bc}$ & $48.9 \pm 0.4$ & $13.7 \pm 0.4 \mathrm{~b}$ & $1.31 \pm 0.09$ & $1.96 \pm 0.04$ & $6.34 \pm 0.21 \mathrm{a}$ & $1.19 \pm 0.10 \mathrm{abc}$ \\
\hline Flood $15^{\circ} \mathrm{C}$ & $342.2 \pm 21.4 \mathrm{a}$ & $27.7 \pm 0.3 \mathrm{ab}$ & $48.8 \pm 0.5$ & $13.8 \pm 0.3 \mathrm{~b}$ & $1.78 \pm 0.09$ & $1.86 \pm 0.07$ & $5.28 \pm 0.15 b$ & $0.83 \pm 0.13 \mathrm{c}$ \\
\hline Flood $25^{\circ} \mathrm{C}$ & $183.4 \pm 18.8 \mathrm{~b}$ & $30.2 \pm 0.6 \mathrm{a}$ & $48.8 \pm 1.1$ & $12.5 \pm 0.8 \mathrm{~b}$ & $1.34 \pm 0.07$ & $1.87 \pm 0.12$ & $4.34 \pm 0.29 \mathrm{c}$ & $0.93 \pm 0.13 b c$ \\
\hline$P$ value & $<0.001$ & $<0.001$ & 0.242 & 0.002 & 0.063 & 0.598 & $<0.001$ & 0.004 \\
\hline \multicolumn{9}{|l|}{ After soil recovery } \\
\hline Control $5^{\circ} \mathrm{C}$ & $306.0 \pm 27.6 \mathrm{a}$ & $25.7 \pm 0.5 \mathrm{a}$ & $47.8 \pm 0.6 \mathrm{bc}$ & $16.0 \pm 0.5 \mathrm{ab}$ & $1.41 \pm 0.07 \mathrm{~b}$ & $2.20 \pm 0.11 \mathrm{ab}$ & $5.25 \pm 0.13 \mathrm{a}$ & $1.60 \pm 0.40 \mathrm{ab}$ \\
\hline Control $15^{\circ} \mathrm{C}$ & $242.0 \pm 5.4 \mathrm{ab}$ & $26.0 \pm 0.1 \mathrm{a}$ & $47.5 \pm 0.3 \mathrm{bc}$ & $17.3 \pm 0.5 \mathrm{ab}$ & $1.48 \pm 0.09 \mathrm{ab}$ & $1.99 \pm 0.14 \mathrm{ab}$ & $4.94 \pm 0.24 \mathrm{a}$ & $0.85 \pm 0.21 \mathrm{ab}$ \\
\hline Control $25^{\circ} \mathrm{C}$ & $269.0 \pm 12.4 \mathrm{a}$ & $27.3 \pm 0.3 \mathrm{ab}$ & $46.0 \pm 0.6 \mathrm{c}$ & $17.7 \pm 0.2 \mathrm{a}$ & $1.93 \pm 0.10 \mathrm{a}$ & $2.01 \pm 0.11 \mathrm{ab}$ & $4.43 \pm 0.16 \mathrm{ab}$ & $0.64 \pm 0.08 \mathrm{~b}$ \\
\hline Flood $5^{\circ} \mathrm{C}$ & $271.3 \pm 4.3 \mathrm{a}$ & $26.1 \pm 0.2 \mathrm{a}$ & $48.0 \pm 0.3 \mathrm{bc}$ & $16.4 \pm 0.1 \mathrm{ab}$ & $1.50 \pm 0.16 \mathrm{ab}$ & $1.75 \pm 0.05 b$ & $5.23 \pm 0.07 \mathrm{a}$ & $1.05 \pm 0.19 \mathrm{ab}$ \\
\hline Flood $15^{\circ} \mathrm{C}$ & $269.4 \pm 16.7 \mathrm{a}$ & $26.0 \pm 0.5 \mathrm{ab}$ & $49.8 \pm 0.7 \mathrm{ab}$ & $15.0 \pm 0.9 \mathrm{bc}$ & $1.46 \pm 0.06 \mathrm{~b}$ & $2.01 \pm 0.18 \mathrm{ab}$ & $4.62 \pm 0.18 \mathrm{ab}$ & $1.12 \pm 0.27 \mathrm{ab}$ \\
\hline Flood $25^{\circ} \mathrm{C}$ & $179.3 \pm 6.7 \mathrm{~b}$ & $26.6 \pm 0.1 \mathrm{~b}$ & $51.1 \pm 0.9 \mathrm{a}$ & $12.9 \pm 0.8 \mathrm{c}$ & $1.29 \pm 0.09 b$ & $2.57 \pm 0.26 \mathrm{a}$ & $3.50 \pm 0.45 \mathrm{~b}$ & $2.03 \pm 0.39 \mathrm{a}$ \\
\hline$P$ value & $<0.001$ & 0.052 & $<0.001$ & $<0.001$ & 0.006 & 0.032 & 0.003 & 0.025 \\
\hline
\end{tabular}

Control: mesocosms without flooding; Flood: mesocosms which were flooded.

Anaerobes anaerobic bacteria, Arb. Myco. putative arbuscular mycorrhizal fungi. 